\title{
EDITORIAL
}

\section{More than just B-cell inhibition}

\author{
Eric M Ruderman and Richard M Pope* \\ See related research by Chang et al., http://arthritis-research.com/content/13/4/R115
}

\begin{abstract}
Despite tremendous advances in the therapy of rheumatoid arthritis (RA), there remains interest in oral agents that may offer benefits that are similar to, or better than, those of biologic therapies. In their paper, Chang and colleagues demonstrate the effectiveness of a Bruton tyrosine kinase (Btk) inhibitor in two models of RA. Btk inhibition impacts several pathways affecting both B-cell and macrophage activation, making it a promising target in RA. However, other kinase inhibitors have failed to transition from animal models to human therapy, so it remains to be seen whether a Btk inhibitor will have a role in the RA treatment armamentarium.
\end{abstract}

Therapy for rheumatoid arthritis (RA) has advanced tremendously over the past 10 years. Biologic therapy employing recombinant antibodies and receptors has become the standard of care. Neutralization of cytokines (tumor necrosis factor-alpha and interleukin-6), inhibition of co-stimulatory pathways (CTLA4Ig), and B-cell depletion (anti-CD20) have all been shown to be effective therapies. However, each requires parenteral administration, is expensive, and may result in undesired side effects. Over the last several years, there have been intensified efforts to develop small-molecule inhibitors that can be taken orally and that may result in less expensive, safer, and more conveniently administered therapy. In this issue of Arthritis Research \& Therapy, Chang and colleagues [1] present data demonstrating the effectiveness of a selective Bruton tyrosine kinase (Btk) inhibitor, PCI-32765, in two experimental models of RA.

Btk was originally identified as defective in patients who had X-linked agammaglobulinemia and who exhibited a profound reduction of B cells. Btk is a non-receptor

*Correspondence: rmp158@northwestern.edu

Department of Medicine, Division of Rheumatology, Northwestern University

Feinberg School of Medicine, 240 E. Huron Street, McGaw M300, Chicago, IL 60611, USA tyrosine kinase within the Tec family of kinases and contains six domains: pleckstrin homogy $(\mathrm{PH})$, Btk homology, polyproline region, two Src homology (SH2 and SH3), and a tyrosine kinase. Though originally identified in B cells (identifying it as a potential B-cell target), it has been found more recently in myeloid cells, including monocytes, macrophages neutrophils, and mast cells [2]. Btk is activated by crosslinking immunoglobulins on the surface of B cells and by the ligation of Fc receptors and integrins on myeloid cells, mediated through Src kinases, including Lyn and Syk [3,4], the latter a promising therapeutic target in RA. Src kinase activation of plasma membrane-bound (through the PH domain) Btk results in tyrosine phosphorylation of tyrosine 551 (in the tyrosine kinase domain), which leads to autophosphorylation at tyrosine 223 (in the SH3 domain), resulting in full kinase activity. Activated Btk drives phosphorylation of PLCY and subsequent PKC activation, which in turn results in the calcium flux and the activation of transcription factors, including nuclear factor-kappa-B (NF-kB) and NF-AT, regulating the expression downstream genes controlling proliferation, survival, and chemokine and cytokine gene expression [2]. PCI-32765, like other Btk inhibitors, was designed to inhibit the activation by selectively interacting with an ATP-binding site in the tyrosine kinase domain, preventing Btk phosphorylation and activation [5-7].

Adding to their previously published observations in collagen-induced arthritis [8], Chang and colleagues [1] convincingly demonstrate the therapeutic effectiveness of PCI-32765 in collagen-induced arthritis, documenting marked reduction of joint swelling, destruction, and inflammatory mediators. However, their prior publication demonstrated that the improvement was due in part to suppression of the anti-collagen antibody response [8], consistent with the results observed with another Btk inhibitor [5]. However, suppression of the collagen antibody-induced arthritis (CAIA) model, which employed anti-collagen antibodies plus the Toll-like receptor 4 (TLR4) ligand lipopolysaccharide (LPS), by both Btk inhibitors demonstrates an effect beyond just suppression of autoantibody production [1,5]. The in vitro studies demonstrate the ability to inhibit B-cell activation and proliferation and to inhibit activation 
through IgG and IgE Fc receptors but not TLR4 [1]. The inability to suppress TLR4 signaling confounds the interpretation of the CAIA model, which employs LPS. In contrast, other studies have documented a role for Btk in macrophage activation through TLR4 $[9,10]$. The ability to suppress TLR signaling might be beneficial in RA since TLR signaling may contribute to the progression of RA mediated by endogenous TLR ligands [11].

How might Btk inhibitors, given their effectiveness in animal models, fit into the armamentarium of therapies for RA? That depends on a number of factors. The first, and most important, is whether success in animal models will translate to efficacy in human disease. The p38 mitogen-activated protein (MAP) kinase experience, in which a number of compounds that demonstrated promising efficacy in preclinical animal models failed to deliver on that promise in clinical studies in patients with RA, taught us a valuable lesson in this regard $[12,13]$. The p38 experience taught us another important lesson as well: the ubiquitous nature of the kinase family, and its presence in so many different cell types, increases the likelihood of off-target effects of inhibitors of these proteins. The similarity of the Btk ATP-binding site to other kinase-binding sites makes this concern relevant. For some of the p38 MAP kinase inhibitors that advanced into clinical trials, this resulted in central nervous system effects and elevated liver enzymes that threatened to overshadow their modest clinical efficacy.

The two kinase inhibitors that have moved farthest into clinical development - tofacitinib, a JAK kinase inhibitor, and fostamatinib, a Syk kinase inhibitor - have successfully bridged the gap between animal models and human clinical efficacy. Moreover, early evidence suggests that they have done so with off-target toxicity that is likely to be acceptable in light of their clinical efficacy. Although this is promising, it remains to be seen whether Btk inhibitors will meet this promise in patients with RA.

\section{Abbreviations \\ Btk, Bruton tyrosine kinase; CAIA, collagen antibody-induced arthritis; LPS, lipopolysaccharide; MAP, mitogen-activated protein; NF, nuclear factor; $\mathrm{PH}$, pleckstrin homogy; RA, rheumatoid arthritis; SH, Src homology; TLR, Toll-like receptor.}

\section{Competing interests}

EMR has received consulting fees from Pfizer Inc (New York, NY, USA). RMP declares that he has no competing interests.

\section{Acknowledgments}

This work was supported in part by National Institutes of Health grant AR055240.
Published: 30 August 2011

\section{References}

1. Chang BY, Huang MM, Francesco M, Chen J, Sokolove J, Magadala P, Robinson WH, Buggy JJ: The Bruton tyrosine kinase inhibitor PCl-32765 ameliorates autoimmune arthritis by inhibition of multiple effector cells. Arthritis Res Ther 2011, 13:R115.

2. Mohamed AJ, Yu L, Bäckesjö CM, Vargas L, Faryal R, Aints A, Christensson B, Berglöf A, Vihinen M, Nore BF, Smith Cl: Bruton's tyrosine kinase (Btk): function, regulation, and transformation with special emphasis on the PH domain. Immunol Rev 2009, 228:58-73.

3. Kurosaki T, Hikida M: Tyrosine kinases and their substrates in B lymphocytes. Immunol Rev 2009, 228:132-148.

4. Rawlings DJ, Scharenberg AM, Park H, Wahl MI, Lin S, Kato RM, Fluckiger AC, Witte ON, Kinet JP: Activation of BTK by a phosphorylation mechanism initiated by SRC family kinases. Science 1996, 271:822-825.

5. Di Paolo JA, Huang T, Balazs M, Barbosa J, Barck KH, Bravo BJ, Carano RA, Darrow J, Davies DR, DeForge LE, Diehl L, Ferrando R, Gallion SL, Giannetti AM, Gribling P, Hurez V, Hymowitz SG, Jones R, Kropf JE, Lee WP, Maciejewski PM, Mitchell SA, Rong H, Staker BL, Whitney JA, Yeh S, Young WB, Yu C, Zhang J, Reif K, Currie KS: Specific Btk inhibition suppresses B cell- and myeloid cell-mediated arthritis. Nat Chem Biol 2011, 7:41-50.

6. Mahajan S, Ghosh S, Sudbeck EA, Zheng Y, Downs S, Hupke M, Uckun FM: Rational design and synthesis of a novel anti-leukemic agent targeting Bruton's tyrosine kinase (BTK), LFM-A13 [alpha-cyano-beta-hydroxy-betamethyl-N-(2, 5-dibromophenyl)propenamide]. J Biol Chem 1999, 274:9587-9599.

7. Pan Z, Scheerens H, Li SJ, Schultz BE, Sprengeler PA, Burrill LC, Mendonca RV, Sweeney MD, Scott KC, Grothaus PG, Jeffery DA, Spoerke JM, Honigberg LA, Young PR, Dalrymple SA, Palmer JT: Discovery of selective irreversible inhibitors for Bruton's tyrosine kinase. Chem Med Chem 2007, 2:58-61.

8. Honigberg LA, Smith AM, Sirisawad M, Verner E, Loury D, Chang B, Li S, Pan Z, Thamm DH, Miller RA, Buggy J): The Bruton tyrosine kinase inhibitor PCl-32765 blocks B-cell activation and is efficacious in models of autoimmune disease and B-cell malignancy. Proc Natl Acad Sci U S A 2010, 107:13075-13080.

9. Horwood NJ, Mahon T, McDaid JP, Campbell J, Mano H, Brennan FM, Webster D, Foxwell BM: Bruton's tyrosine kinase is required for lipopolysaccharideinduced tumor necrosis factor alpha production. J Exp Med 2003, 197:1603-1611.

10. Vijayan V, Baumgart-Vogt E, Naidu S, Qian G, Immenschuh S: Bruton's tyrosine kinase is required for TLR-dependent heme oxygenase-1 gene activation via Nrf2 in macrophages. J Immunol 2011, 187:817-827.

11. Huang Q, Pope RM: Toll-like receptor signaling: a potential link among rheumatoid arthritis, systemic lupus, and atherosclerosis. J Leukoc Biol 2010, 88:253-262.

12. Hammaker D, Firestein GS: "Go upstream, young man": lessons learned from the p38 saga. Ann Rheum Dis 2010, 69 Suppl 1:i77-82.

13. Hill RJ, Dabbagh K, Phippard D, Li C, Suttmann RT, Welch M, Papp E, Song KW, Chang KC, Leaffer D, Kim YN, Roberts RT, Zabka TS, Aud D, Dal Porto J, Manning AM, Peng SL, Goldstein DM, Wong BR: Pamapimod, a novel p38 mitogen-activated protein kinase inhibitor: preclinical analysis of efficacy and selectivity. J Pharmacol Exp Ther 2008, 327:610-619.

doi:10.1186/ar3439

Cite this article as: Ruderman EM, Pope RM: More than just B-cell inhibition. Arthritis Research \& Therapy 2011, 13:125. 